\title{
Intervenciones breves en alcohol como rutina diaria. Proyecto de investigación acción de directrices para atención primaria
}

\author{
Brief alcohol intervention as a daily routine. Description of \\ an action research project creating instructions for primary \\ health care
}

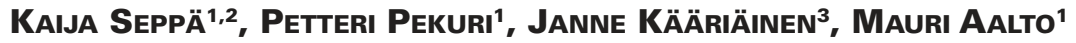 \\ 1) Departamento de Psiquiatría, Hospital Universitario de Tampere. Department of Psychiatry, Tampere University Hospital . \\ 2) Departamento de Medicina General, Universidad de Tampere. Department of General Practice, University of Tampere. \\ 3) Departamento de Otorrinolaringología, Hospital Universitario de Tampere. Department of Otorhinolaryngology, Tampere University Hospital. \\ Enviar correspondencia a: \\ Kaija Seppä. Medical School. Department of General Practice. FIN 33014 University of Tampere. FINLAND. Phone +358 32157101. Fax +358 32156722. \\ Email: mekase@uta.fi
}

Recibido: 6 de septiembre de 2004 Aceptado: 4 de octubre de 2004

\section{RESUMEN}

Los profesionales de la atención primaria apenas realizan intervenciones breves en alcohol. El objetivo del presente estudio es ver hasta qué punto y cómo podrían incorporarse estas intervenciones breves a su trabajo diario. El estudio incluye un cuestionario para el personal de atención primaria, la grabación en video de grupos de discusión de profesionales, y un cuestionario para los pacientes de atención primaria en Tampere (Finlandia), una ciudad de aproximadamente 200.000 habitantes. El método empleado ha sido el análisis cualitativo (categorizado) de las tres fuentes de información (cuestionario de profesionales, cuestionario de pacientes, grupos de discusión) y de las discusiones sobre el tema con el personal.

La actitud positiva de pacientes y profesionales hacia las intervenciones breves proporcionó la base ética para elaborar directrices. Médicos y enfermeros deseaban unas instrucciones muy prácticas y sucintas, pero creían que sólo era posible realizar intervenciones breves en determinadas situaciones, no de forma sistemática; preferían la comunicación verbal a los cuestionarios estructurados, y querían información escrita para los pacientes e instrucciones muy claras en las que apoyarse. Se elaboraron, así, unas breves directrices que todos aceptaron, basadas en la información y en la retroalimentación.

Es posible encontrar el modo de que los profesionales de la atención primaria realicen intervenciones breves en alcohol. Éste puede variar de una cultura a otra, y deberá ajustarse a cada caso específico, pero los métodos aquí empleados son aplicables en cualquier parte del mundo.

Palabras clave: investigación acción, actitudes, intervenciones breves, consumo de alcohol de riesgo, atención primaria.

\section{ABSTRACT}

Brief alcohol intervention is poorly taken up by primary health care professionals. The aim of the present study was to see whether and how brief intervention could be done as part of everyday work. The study included a questionnaire to primary care staff, videotaped focus groups of professionals, and a questionnaire to patients in primary health care setting in the City of Tampere, Finland, with about 200000 inhabitants. The method was qualitative (categorized) analysis of the three sources of information (questionnaire to professionals, questionnaire to patients, focus groups) and discussions by the staffs during the action.

Patients' and professionals' positive attitudes towards brief intervention provided the ethical ground to create instructions. Nurses and general practitioners wanted short, practical instructions, but felt that it was feasible to do brief intervention only in certain situations, not systematically; they preferred verbal communication to structured questionnaires, and wanted written information for patients and clear instructions when to refer. Based on information and feedback, short instructions were created and accepted by staff.

It is possible to find a way for primary health care professionals to do brief alcohol intervention. This may differ in different cultures and should be individually tailored, but the methods used here are globally applicable.

Key words: Action research, attitudes, brief intervention, risky drinking, primary health, care. 


\section{INTRODUCCIÓN}

$\mathbf{L}$ a eficacia de las intervenciones breves en los consumidores abusivos de alcohol que no han desarrollado una adicción, conocidos como bebedores de riesgo, es incuestionable (Kahan y col. 1995, Wilk y col. 1997, Salaspuro, 2001, Moyer y col. 2002, Ballesteros y col. 2004). La rentabilidad también ha demostrado ser alta y el efecto parece durar varios años (Fleming y col. 2000, Fleming y col. 2002). Por ese motivo, la implementación generalizada de las intervenciones breves debería resultar enormemente beneficiosa para la salud pública. Esa implementación es fundamental sobre todo en la atención primaria, que cubre anualmente un elevado porcentaje de población.

A pesar de todos los esfuerzos para promover las intervenciones breves, su puesta en práctica ha continuado siendo escasa (Adams y col. 1997, Kaner y col. 1999, Andréasson y col. 2000, Beich y col. 2002). Las posibles causas de esto residirían en el apoyo insuficiente de los líderes de opinión, en la escasez de tiempo y de recursos, y en otros obstáculos como las actitudes y la falta de habilidades o conocimientos (Weller y col. 1992, McDuffy y col.1995, Roche y col. 1995, Adams y col. 1997, Kääriäinen y col. 2001, Roche y Freeman 2004).

El gran reto que debemos afrontar en nuestros días es cómo implementar las intervenciones breves como una parte del trabajo diario en la atención sanitaria. El estudio colaborativo WHO Fase IV (www.who-alcoholphaseiv.net) trata básicamente de encontrar medios flexibles de identificación precoz e intervenciones breves que pueden ser implementadas en la atención primaria. Este proyecto es la rama finlandesa del estudio WHO Fase IV: antes de la implementación queríamos averiguar qué clase de identificación precoz y de intervenciones breves (si existen) resultarían factibles como parte del trabajo diario en la atención primaria.

\section{MÉTODOS}

El presente estudio se realizó en Tampere, ciudad de unos 200.000 habitantes, al sur de Finlandia. El Centro de Salud Pública de Tampere cuenta con 77 médicos de familia (GP) y 177 enfermeros para atender a toda su población. La ciudad es representativa del resto del país, incluyendo las áreas rurales y urbanas. El consumo de alcohol de sus habitantes $(7.7 \mathrm{~L}$ de alcohol puro/año) es semejante al del nivel medio finlandés (7.6 L/año). De los médicos de familia (GP), el 52\% están especializados en medicina general (porcentaje nacional $56 \%$ ), el $73 \%$ son mujeres (porcentaje nacio-

\section{INTRODUCTION}

$T$ he evidence of brief intervention for nondependent alcohol abusers, so called risky drinkers, is convincing (Kahan et al. 1995, Wilk et al. 1997, Salaspuro, 2001, Moyer et al. 2002, Ballesteros et al. 2004). Also, the cost-effectiveness has been proven to be high and the effect seems to last for several years (Fleming et al. 2000, Fleming et al. 2002). Thus, widespread implementation of brief intervention should lead to a big public health benefit. Implementation is especially important in primary health care, which reaches high proportion of the population every year.

In spite of all the efforts to promote brief intervention, activity has remained low (Adams et al. 1997, Kaner et al. 1999, Andréasson et al. 2000, Beich et al. 2002). The possible reasons may lie in insufficient commitment of opinion leaders, lack of time and resources, and obstacles like attitudes and poor skills and knowledge (Weller et al. 1992, McDuffy et al.1995, Roche et al. 1995, Adams et al. 1997, Kääriäinen et al. 2001, Roche and Freeman 2004)

The big challenge now is how to implement brief intervention as part of everyday work in health care. The WHO Phase IV collaborative study (www.whoalcohol-phaseiv.net) concentrates on trying to find flexible ways of early detection and brief intervention that can be implemented in primary health care. The present project is the Finnish arm of the WHO Phase IV study: before implementation we wanted to find out what kind of early identification and brief intervention (if any) would be feasible as part of everyday work in primary health care.

\section{METHODS}

The present study took place in the city of Tampere in Southern Finland, which has about 200000 inhabitants. Tampere Communal Health Centre serves all inhabitants in the city with 77 general practitioners (GP) and 177 nurses. The city is representative of the whole country, including rural and urban areas. Alcohol consumption of the inhabitants $(7.7 \mathrm{~L}$ of absolute alcohol per year) is the same as the average Finnish level (7.6 L/year). Of the GPs, 52\% are specialized in 
nal $60 \%$ ) y la edad media es de 43 años (porcentaje nacional 40-45 años).

Se envió por correo un cuestionario estructurado (con entre dos y seis opciones de respuesta para cada pregunta individual) a todos los médicos de familia y enfermeros del Centro de Salud Pública de Tampere, a fin de averiguar sus actitudes (sobre si preguntar o no a los pacientes si consumían alcohol, realizar intervenciones breves), su grado de conocimiento (de las intervenciones breves, cuestionarios, definición de consumo de riesgo de bebidas alcohólicas), creencias (qué opinan los pacientes de que se hable del tema), habilidades (motivar a los pacientes, preguntarles sobre el alcohol, realizar intervenciones breves) y necesidad de formación (Aalto y col. 2001).

Seis grupos de discusión (de las siete clínicas del Centro de Salud), incluyendo 18 médicos de familia y 19 enfermeros, fueron animados a buscar información sobre los obstáculos de las intervenciones breves (Aalto y col., 2003). Uno de los siete centros no participó debido a la dificultad de sus miembros para encontrar tiempo para reunirse. Se contactó en primer lugar con los directores de los seis centros. A fin de conseguir participantes representativos y de obtener toda la información posible de las sesiones de trabajo, se les comunicó que el grupo debería incluir tanto enfermeros como médicos de familia, de ambos sexos y con distintas opiniones sobre el trabajo con pacientes con problemas vinculados al consumo de alcohol.

Por otra parte, se realizó una encuesta en dos de las siete clínicas a 665 de los 1000 pacientes que salieron consecutivamente de la consulta, con el fin de averiguar si y cuándo los médicos de familia y los enfermeros les habían preguntado y/o aconsejado sobre el consumo de alcohol (Aalto y col. 2002). Cada una de las dos clínicas atiende a una población aproximada de 30.000 habitantes, tanto urbanos como suburbanos. Un total de 14 médicos de familia y 10 enfermeros trabajaban en esos dos centros durante los períodos estudiados. Tanto la población como los profesionales representan adecuadamente al resto de la ciudad. El cuestionario preguntaba sobre el sexo, la edad y el consumo de alcohol de los pacientes. Las dos cuestiones siguientes se incluían para evaluar la actividad de los profesionales en las intervenciones breves: "¿Cuándo le preguntó por última vez algún médico o enfermero de esta clínica sobre su consumo de alcohol?" (las respuestas posibles eran hoy, durante el último año, hace más de un año o nunca) y " ¿Le aconsejó algún doctor o enfermero sobre el consumo de alcohol en esta consulta?" (las respuestas posibles eran sí o no).

Las tres encuestas y la información de retroalimentación (debates) recogidas durante el proyecto por el médico Mauri Aalto y el enfermero Petteri Pekuri fueron analizadas por separado por tres de los autores general practice (national percentage 56\%), 73\% are women (nationally 60\%) and mean age is 43 years (nationally 40-45 years).

A structured questionnaire (with two to six answer options to each individual question) was mailed to all GPs and nurses working at Tampere City Communal Health Centre to find out their attitudes (in relation to asking about patients' alcohol consumption and doing brief intervention), knowledge (about brief intervention, questionnaires, definition of hazardous drinking), beliefs (what patients think about discussing), skills (motivating patients, asking about alcohol, doing brief intervention) and need for training (Aalto et al. 2001).

Six focus groups (out of the seven clinics in the health centre), including 18 GPs and 19 nurses, were run to get information of the obstacles to brief intervention (Aalto et al., 2003). One of the seven centers did not participate because of difficulties in finding time for the focus group meeting. The chiefs of the six centres were first contacted. To find representative participants and to get all possible information from the group sessions the information was given, that the group should include both nurses and GPs, both genders and professionals with diverse opinions in relation to working with patients with alcohol problems.

Additionally, a survey was performed at two of the seven clinics of 665 out of 1000 consecutive patients after consultation, to find out if and when GPs or nurses had asked and/or advised about their drinking (Aalto et al. 2002). Each of these two clinics provides services for a population of about 30,000, both urban and suburban. A total of 14 general practitioners and 10 nurses were working in these two centres during the study periods. The population and professionals well represent the whole city. The questionnaire contained questions on patients' gender, age, and alcohol consumption. The two following questions were included to evaluate the professionals' activity to do brief intervention: 'When did a doctor or nurse at this clinic last ask about your alcohol drinking?' (answer options today, during the past year, over a year ago or never) and 'Did a doctor or nurse advise you about alcohol drinking at this consultation?' (answer options yes or no).

All three surveys, and feedback information (discussions) collected during the action project by the project physician (Mauri Aalto) and the project nurse (Petteri Pekuri) were separately analyzed 
del estudio (Kaija Seppä, Petteri Pekuri, Mauri Aalto). Las conclusiones se clasificaron del siguiente modo: 1) bases éticas para debatir sobre el alcohol 2) herramientas factibles para los profesionales a la hora de realizar intervenciones breves 3) manera idónea de realizar intervenciones breves. Después se desarrollaron una serie de directrices, que se presentaron ante los integrantes del grupo de trabajo para averiguar si las interpretaciones eran válidas y reflejaban fielmente lo que los profesionales sabían. Las diferentes fases en la creación de unas directrices aparecen en la Figura 1. blind by three of the authors (Kaija Seppä, Petteri Pekuri, Mauri Aalto). Findings were categorized as 1) ethical grounds for discussing alcohol, 2) tools that professionals find feasible in doing brief intervention and 3 ) best way to do brief intervention. Instructions were then developed, and introduced to the focus group participants to find out whether the interpretations were valid and accurately reflected the professionals' understanding. The different phases in creating the instructions are presented in Figure $\mathbf{1}$

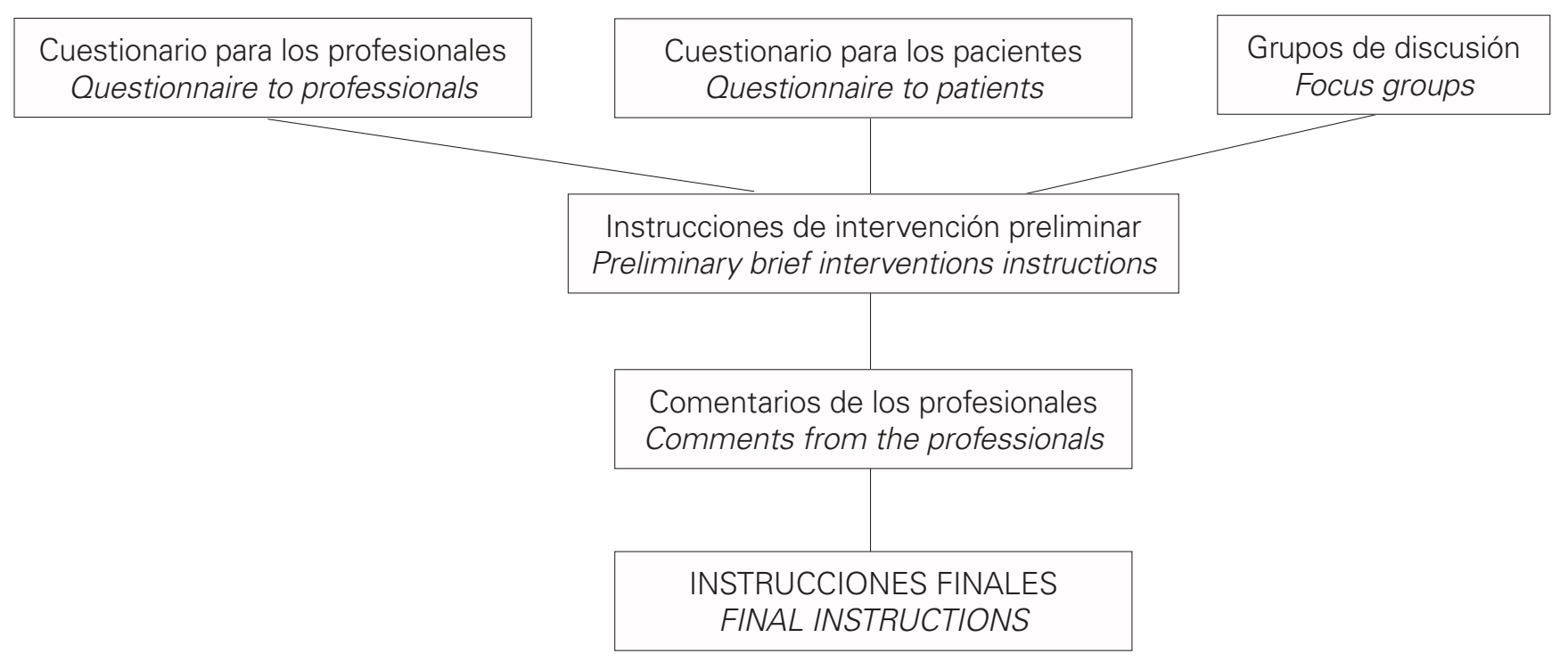

Figura1. Las fases en la creación de instrucciones para la identificación precoz y las intervenciones breves Figure 1. The phases in creating the early identification and brief intervention instructions.

\section{RESULTADOS}

El cuestionario de los profesionales (Aalto y col. 2001) nos proporcionó la justificación ética para continuar con la implementación; las actitudes eran positivas y los profesionales de la salud consideraban importantes las intervenciones breves. El cuestionario de pacientes mostró también su apoyo a esta actividad; sólo una pequeña minoría $(<2 \%)$ adoptaba una actitud negativa hacia el hecho de hablar sobre el alcohol con un profesional (Aalto y col. 2002). Sin embargo, el índice de pacientes que participaron en la encuesta fue bastante bajo. Es posible que los problemas relacionados con el alcohol sean más comunes entre los pacientes que no respondieron. Puesto que los consumidores abusivos de alcohol se mostraron algo más reacios que los demás a hablar del tema, el porcentaje total de pacientes a favor de las intervenciones breves puede ser excesivo.

\section{RESULTS}

The questionnaire to professionals (Aalto et al. 2001) gave us the ethical justification to proceed with implementation; the attitudes were positive and health professionals considered brief intervention important. The questionnaire to the patients also supported the activity; only a small minority $(<2 \%)$ had a negative attitude towards talking about alcohol with a professional (Aalto et al. 2002). However, the participation percentage to the patient survey was rather low. Alcohol problems may be more common among those patients who did not reply. Thus, because heavy drinkers were a little more negative about discussing than others, the overall proportion of patients being positive may be overestimated. 
La necesidad de unas directrices prácticas y escuetas para la identificación precoz y las intervenciones breves surgió de los grupos de discusión; la preocupación por la falta de unas instrucciones básicas estuvo muy presente en los seis grupos. Ellos nos ayudaron, asimismo, a definir las situaciones y la forma en que médicos de familia y enfermeros estaban deseando realizar esas intervenciones breves. Los profesionales más experimentados consideraban que las preguntas directas, en lugar de los cuestionarios estructurados, eran de más utilidad para conocer detalles sobre el consumo de alcohol de sus pacientes; los médicos de familia más jóvenes, por el contrario, deseaban tener un cuestionario. De los cuestionarios disponibles, el preferido fue el test AUDIT -Test de Identificación para los Trastornos relacionados con el Consumo de Alcohol- (Saunders y Aasland 1987). EI AUDIT fue elegido, no debido a su superioridad, o porque, al ser "autoadministrable", ahorrara tiempo, sino porque los profesionales jóvenes no creían tener suficiente habilidad para discutir el tema de forma directa.

Una opinión muy extendida era que, en lugar de una revisión sistemática, algunas dolencias o situaciones (por ejemplo un chequeo médico) justificarían preguntar (incluyendo el test AUDIT) y aconsejar: éstas podrían ser, además de chequeos médicos, accidentes, tensión alta, arritmias, trastornos del sueño, depresión, ansiedad, dolores abdominales, resacas, y valores altos en unos análisis (por ejemplo, en el serum glutamiltransferasa, serum desialotransferrín o volumen corpuscular medio de eritrocitos). Se repartió un folleto con información sobre el alcohol, que sirviera de ayuda al personal que debía orientar a los pacientes, y como el tiempo a menudo escaseaba, se sugirió una segunda consulta. Los trabajadores de atención primaria no se sentían cómodos tratando pacientes adictos al alcohol; así que recibieron instrucciones para derivar esos pacientes a un especialista si el resultado del AUDIT era $>14$.

Como muchos de los profesionales con mayor experiencia deseaban hacer más, estas instrucciones se consideraron un "modelo mínimo" que permitía seguir trabajando. Había que rellenar el test AUDIT, entregar al paciente el folleto de información si el resultado del AUDIT $\geq 8$ pero menor de 15, y acordar con él una nueva consulta.

Cuando estos resultados se presentaron ante los integrantes de los grupos de discusión, no cambiaron su opinión de no someter a revisión a todos los pacientes. Se acordó que las revisiones serían oportunistas y que sólo determinadas situaciones justificarían preguntar a los pacientes sobre su consumo de alcohol. Las instrucciones finales (Tabla 1) fueron enviadas por correo a todo el personal del Centro de Salud Pública de Tampere, con una carta adjunta.
The need for short and practical instruction on early identification and brief intervention arose from focus groups; worry about lack of simple guidelines was prominent in all six groups. They also helped us to define situations and ways, in which GPs and nurses were willing to do brief intervention. Those with long experience considered that asking instead of structured questionnaires was a better way of learning about patients' alcohol consumption; younger GPs on the contrary wished for a questionnaire. Of questionnaires available the Alcohol Use Disorders Identification Test (AUDIT) (Saunders and Aasland 1987) was preferred. AUDIT was chosen, not because of its superiority, or because it, as selfadministered, is not time-consuming but because the young professionals felt not to have skills for direct discussion

A common opinion was that, instead of systematic screening, certain complaints or situations (for example health check-ups) would justify asking (including AUDIT-questionnaire ) and counseling: these included health check ups, accidents, high blood pressure, arrhythmia, sleep disorders, depression, anxiety, abdominal complaints, hangover, and increased values in laboratory tests such as serum glutamyltransferase, serum desialotransferrin or mean erythrocyte corpuscular volume). A written, patient information leaflet about alcohol was introduced to support staff counseling, and because time was often at a premium, at least one follow-up consultation was suggested. Primary care workers did not feel comfortable treating alcohol-dependent patients; thus they were instructed to refer the patient to a specialist clinic if the AUDIT-score was $>14$.

Because many of the more experienced staff were willing to do more, these instructions were considered the "mini-model"; e.g. more was allowed to do. So this consists of filling in the AUDIT questionnaire and giving the patient information leaflet if the score is $\geq 8$ but smaller than 15 and arranging one follow-up consultation agreed with the patient.

When these results were presented to focus group participants, they did not make them change their opinion not to screen every patient. It was thus agreed that screening would be opportunistic and only the selected situations justified asking about patients' alcohol consumption. The final instructions

(Table 1) were mailed to all staff in Tampere City Health Centre, with a covering letter. 
Tabla 1. Instrucciones para la identificación precoz y las intervenciones breves en bebedores de riesgo Table 1. Instructions for early identification and brief intervention of risky drinking developed in collaboration with primary health care professionals.

Esto es lo mínimo que se debe hacer. Pero se puede hacer más si se quiere

PEDIR AL PACIENTE QUE RELLENE EL AUDIT (Alcohol Use Disorders Identification Test) EN LAS SIGUIENTES SITUACIONES:

- Chequeo de salud

- Accidente o traumatismo

- Tensión arterial alta

- Arritmia

- Desordenes en el sueño

- Depresión

- Ansiedad

- Molestias abdominales

- Resaca

- Análisis de sangre anormales indicadores de consumo de riesgo (GGT, CDT, VCM)

\section{ESCRIBA LA PUNTUACIÓN DEL PACIENTE EN SU} HISTORIAL

\section{SI LA PUNTUACIÓN ESTÁ ENTRE 8-14:}

- informe al paciente personalmente de los riesgos del alcohol en conexión con los síntomas del paciente, negocie con el paciente cuanto va a disminuir el consumo y de que forma y déle información escrita (o, por lo menos, déle la información escrita)

- cítelo para otro día

SI LA PUNTUACIÓN ES >14:

- Refiera al paciente a un especialista
This is the minimum what to do - more can be done if preferred

ASK THE PATIENT TO FILL IN AUDIT (Alcohol Use Disorders Identification Test) IN THE FOLLOWING SITUATIONS:

health check-up

accident or trauma

u high blood pressure

a arrhythmia

- sleep disorder

depression

anxiety

口 abdominal complaints

uhang-over

- abnormal blood test value indicative of risky drinking (s-GT, S.CDT, MCV)

\section{WRITE DOWN THE AUDIT SCORE TO PATIENT} DOCUMENTS

\section{WHEN AUDIT SCORE IS 8-14}

- inform the patient personally of the health risks of alcohol primarily in connection to the patient's complaints, negotiate with the patient of how and how much to decrease and give the written information (or at least give the written information)

- make a new appointment

WHEN AUDIT SCORE IS $>14$

- you can refer the patient to a specialist clinic

\section{DISCUSIÓN}

Se han utilizado diversas fuentes a fin de recoger información para las instrucciones de las intervenciones breves: un cuestionario para profesionales (Aalto y col. 2001), grupos de discusión integrados por profesionales (Aalto y col. 2003) y un cuestionario para pacientes (Aalto y col. 2002). Con este propósito, los investigadores combinaron y analizaron la información disponible para elaborar unas directrices con el consenso de todos, que ayudaran tanto en la identificación precoz como en las intervenciones breves. Las directrices fueron nuevamente evaluadas antes de distribuir la versión final.

\section{DISCUSSION}

Several sources were used in gathering information for the brief intervention instructions: a questionnaire to professionals (Aalto et al. 2001), focus groups of professionals (Aalto et al. 2003) and questionnaire to patients (Aalto et al. 2002). For the present purpose the available information was combined, and analyzed by the researchers to produce instructions that can be considered as a validated consensus for a local, early identification and brief intervention package. The instructions were further iteratively retested before the final version was distributed. 
Nuestra impresión de que los profesionales de la salud prefieren las revisiones oportunistas a las sistemáticas coincide con la de otros investigadores (Kaner y col. 1999, Kaner y col. 2001), y la falta de tiempo percibida puede haber despertado el deseo de contar con unas directrices muy sencillas, bajo la forma de un folleto informativo.

Cambiar las prácticas en la asistencia sanitaria es difícil (Greco y Eisenberg 1993, Glanville y col. 1998). Freemantle (2000) comparó diferentes métodos de cambiar las prácticas clínicas, incluyendo la asistencia a congresos y otras actividades destinadas a la educación médica, los consejeros educativos, las intervenciones de líderes de opinión, las supervisiones y la retroalimentación. Ninguno de estos métodos repercutió seriamente en la práctica clínica. De ahí que la implementación ajustada a la práctica, combinando distintos métodos, pueda ser el camino a seguir. Nuestro modelo mínimo establece esa base en el contexto de la cultura de atención sanitaria finlandesa. Incluso así, los obstáculos que pueden entorpecer el avance son muy variados; por ejemplo, la escasa inclinación de los médicos a trabajar en atención primaria, lo que supone un número insuficiente de médicos de familia, una mayor carga de trabajo, y una falta de interés por la medicina preventiva. Por ese motivo, la implementación es también un reto para desarrollar unas condiciones que vuelvan atractivo el trabajo en la atención primaria. Un obstáculo serán aquellos médicos de familia que, debido a sus actitudes hacia las adicciones, escapen a cualquier intento de formación. De ahí que las directrices creadas en colaboración con los profesionales constituyan sólo una pequeña parte, aunque sin duda esencial, de un complicado proceso de implementación.

El presente estudio muestra cómo el desarrollo de unas directrices para las intervenciones breves es un proceso policefacético, con toda probabilidad muy supeditado a la cultura nacional. Es posible que las directrices aquí elaboradas no sirvan a otras culturas, pero que el modo de crearlas es universal.

\section{AGRADECIMIENTOS}

Queremos agradecer su colaboración a todos los médicos de familia y los enfermeros del Centro de Salud de Tampere. El estudio forma parte del proyecto colaborativo WHO Fase IV, destinado a la implementación generalizada de la identificación precoz y de las intervenciones breves en la asistencia primaria; deseamos dar las gracias a todo el equipo. El estudio ha sido financiado por el Ministerio de Asuntos Sociales y Sanidad de Finlandia.
Our finding that health professionals prefer opportunistic to systematic screening is similar than that of other researchers (Kaner et al. 1999, Kaner et al. 2001), and perceived lack of time may have led to the wish to have simple patient instructions, in the form of information leaflet.

Changing practices in health care is difficult (Greco and Eisenberg 1993, Glanville et al. 1998). Freemantle (2000) compared different methods of changing clinical practice, including attendance at conferences and other continuing medical education activities, academic detailing, opinion leader interventions, audit and feedback. None of these alone had any substantial impact on clinical practice. Thus, implementation tailored to working practice and combining different methods, may be the way ahead. Our mini-model forms such a basis in the context of Finnish health care culture. Even so, several obstacles may hamper progress, for example, the unwillingness of physicians to work in primary health care leading to lack of GPs, increasing work load, and lack of interest in preventive medicine. Thus, implementation is also a challenge to management on how to develop conditions so that the work in primary health care becomes attractive. One obstacle will be those GPs who, because of their attitudes towards addictions, cannot be reached for training. Thus, instructions created in collaboration with target professionals only form a small, but essential, part of a complicated implementation process.

The present study demonstrates how developing instructions for brief intervention is a many-faceted process, probably highly dependent on national culture. The instructions created here may not fit other cultures but the way to produce them may be universal.

\section{ACKNOWLEDGEMENTS}

We want to thank all the GPs and nurses at Tampere Health Centre for collaboration. The study is part of WHO Phase IV collaborative project on widespread implementation of early identification and brief intervention in primary health care; our thanks are due to the whole team. The study was funded by the Ministry of Social Affairs and Health, Finland. 


\section{REFERENCIAS / REFERENCES}

Aalto M, Pekuri P, Seppä, K. (2001) Primary health care nurses' and physicians' attitudes, knowledge and beliefs regarding brief intervention for heavy drinkers. Addiction 96:305-311.

Aalto M, Pekuri P, Seppä K. (2002) Primary health care personnels' activity in intervening in patients' alcohol drinking: a patient perspective. Drug and Alcohol Dependence 66 :39-43.

Aalto M, Pekuri P, Seppä, K. (2003) Obstacles to carrying out brief intervention for heavy drinkers in primary health care: a focus group study. Drug and Alcohol Review 22:169-173.

Adams PA, Powell A, McCormick R, Paton-Simpson G. (1997) Incentives for general practitioners to provide brief interventions for alcohol problems. New Zeeland Medical Journal 110:291-294.

Andréasson S, Hjalmarsson K, Rehnman C. (2000) Implementation and dissemination of methods for prevention of alcohol problems in primary health care: a feasibility study. Alcohol \& Alcoholism 35:525-30.

Ballesteros J, Duffy J, Querejeta I, Arino J, Gonzalez-Pinto A. (2004) Efficacy of brief interventions for hazardous drinkers in primary care: systematic review and meta-analysis. Alcoholism: Clinical and Experimental Research 28:608-618.

Beich A, Gannik D, Malterud K. (2002) Screening and brief intervention for excessive alcohol use: qualitative interview study of the experiences of general practitioners. British Medical Journal 325:870-2.

Fleming MF, Mundt MP, French MT, Manwell LB, Stauffacher EA, Barry, KL (2000) Benefit-cost analysis of brief physician advice with problems drinkers in primary care settings. Medical Care 38:7-18.

Fleming MF, Mundt MP, French MT, Manwell LB, Stauffacher EA, Barry, KL. (2002) Brief physician advice with problems drinkers: long-term efficacy and benefitcost analysis. Alcoholism: Clinical and Experimental Research 26:36-43.

Freemantle N. (2000) Implementation strategies. Family Practice 17:Suppl 1 :7-10.

Glanville J, Haines M, Auston, I.(1998) Getting research findings into practice: finding information on clinical effectiveness. British Medical Journal 317:200-203.

Greco PJ, Eisenberg JM. (1993) Changing physicians' practices. New England Journal of Medicine 329:1271-1274.

Kahan M, Wilson L, Becker L. (1995) Effectiveness of physician-based interventions with problem drinkers: a review. Canadian Medical Association Journal 152:851-9.
Kaner EFS. Heather N, McAvoy BR, Lock CA, Gilvarry E. (1999) Intervention for excessive alcohol consumption in primary health care: attitudes and practices of English general practitioners. Alcohol \& Alcoholism 34:559-566.

Kaner EF, Heather N, Brodie J, Lock CA, McAvoy BR. (2001) Patient and practitioner characteristics predict brief alcohol intervention in primary care. British Journal of General Practice 51:822-827.

Kääriäinen J, Sillanaukee P, Poutanen, Seppä, K. (2001) Opinions on alcohol-related issues among professionals in primary, occupational, and specialized health care. Alcohol \& Alcoholism 36:141-146.

McDuffy DR, Tommasello AC, Hoffman KJ, Johanson JL. (1995) Addictions training for physicians and other licensed health care professionals in Maryland. Maryland Medical Journal 44:453-459.

Moyer A, Finney JW, Swearingen CE, Vergun P. (2002) Brief interventions for alcohol problems: a meta-analytic review of controlled investigations in treatment-seeking and non-treatment-seeking populations. Addiction 97:279-292.

Roche AM, Parle MD, Cambell J, Saunders JB. (1995) Substance abuse disorders: psychiatric trainees' knowledge, diagnostic skills and attitudes. Australian and New Zeeland Journal of Psychiatry 29:645-652.

Roche AM, Freeman T. (2004) Brief interventions: good in theory but weak in practice. Drug and Alcohol Review 23:11-18.

Salaspuro M. Intervention mot riskfylld alkoholkonsumption - sekundär prevention av alkoholproblem. In Berglund M, Andréasson S, Franck J, Fridell M, Håkanson I, Johansson B-A et al, editors. (2001) Behandling av alcohol- och narkotikaproblem. The Swedish Council on Technology Assessment in Health Care. $1^{\text {st }}$ ed, Stockholm, Vol I 31-80.

Saunders JB, Aasland, O.G. (1987) WHO Collaborative Project on the Identification and Treatment of Persons with Harmful Alcohol Consumption. Report on Phase I: Development of a Screening Instrument. Geneva: World Health Organization.

Weller DP, Litt JCP, Pols RG, Ali RL, Southgate DO, Harris RD. (1992) Drug and alcohol related health problems in primary care - what do GPs think? Medical Journal of Australia 156:43-48.

Wilk Al, Jensen NM, Havighurst TC.(1997) Meta-analysis of randomized control trials addressing brief interventions in heavy alcohol drinkers. Journal of General Internal Medicine 12:274-83. 